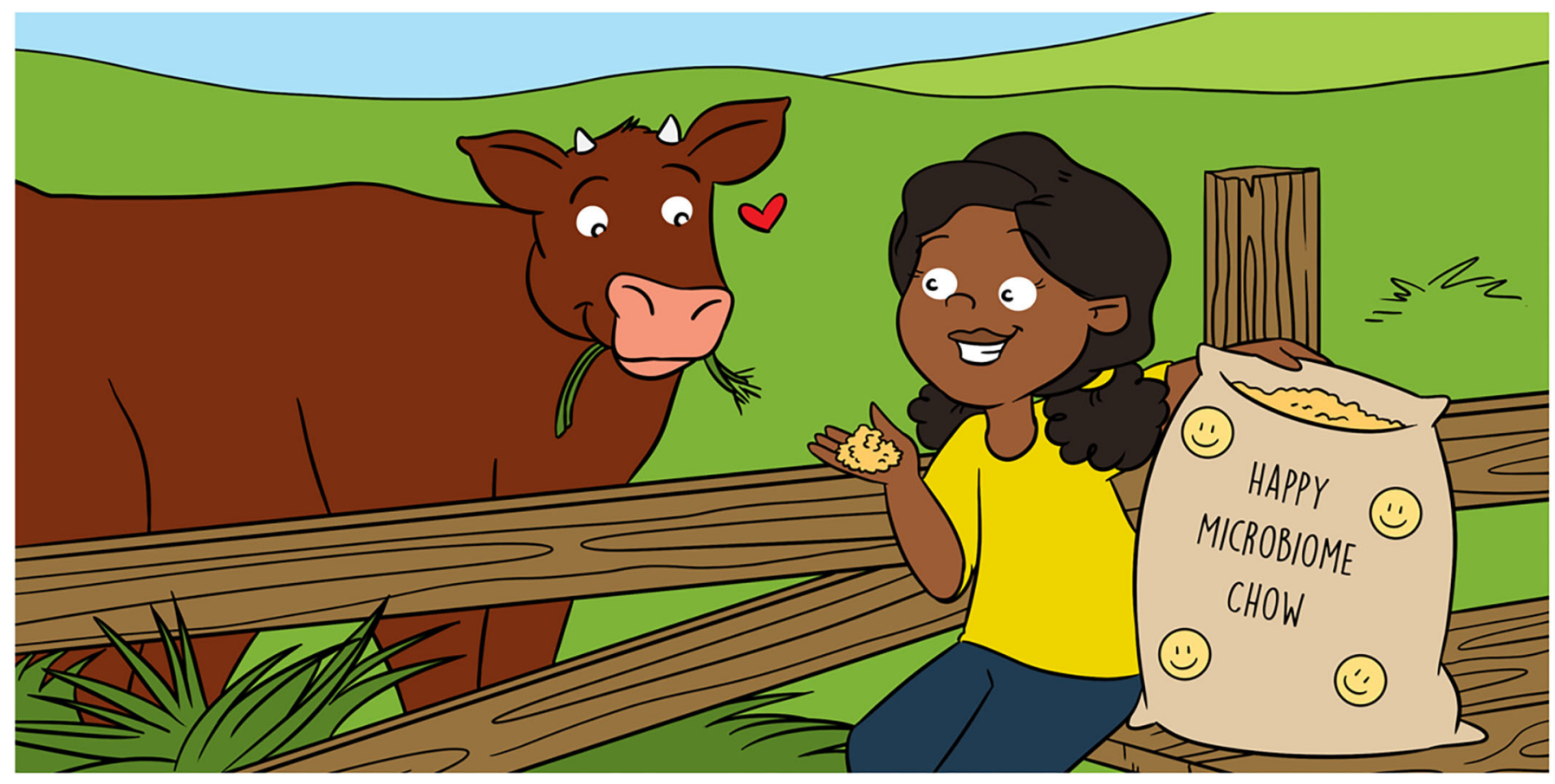

\title{
GETTING BIG COWS BY FEEDING THEIR TINY MICROBES
}

\section{Brooke A. Clemmons ${ }^{1 *}$ and Emma Hernandez-Sanabria ${ }^{2 *}$}

${ }^{1}$ Department of Agriculture, Texas A\&M University - Commerce, Commerce, TX, United States

${ }^{2}$ VIB - KU Leuven Center for Microbiology, Laboratory of Molecular Bacteriology, Rega Institute, Leuven, Belgium

YOUNG REVIEWERS:

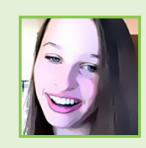

MADDIE

AGE: 15

MATÍAS

AGE: 14

SADIE

AGE: 15

SEBASTIAN

AGE: 10

TACY

AGE: 13
Cattle are used for many purposes, but today beef cattle are mainly raised to provide people with meat and many other useful products. Did you know that leather, soap, gelatin, and even medicines come from beef animals? Besides, cattle can thrive on low-quality land not suitable for building houses or growing plants for people to eat. More importantly, they eat foods that other animals cannot use up. Cows rely on plants as their main source of food and they can digest tough plant parts because they have a team of microbes in their gut. The microbes in this tiny team (called the microbiome) provide cattle with about $70 \%$ of the energy they need. As the microbe team is very important for cattle to grow and get nutrients from food, scientists are working on strategies to get bigger, healthier cows while, at the same time, caring for our planet. 
Figure 1

Microbes of different types and sizes exist in the rumen of cattle (left). Prokaryotes, including archaea and bacteria, are smaller than eukaryotes, which include protozoa and fungi. In the middle figure, can you recognize the small papillae, shaped like fingers, where the microbes live? The entire rumen, including the hand-like pillars that mix and squish the food, is shown on the right.

\section{RUMINANTS}

An animal that eats plant-based foods and breaks them down using the rumen.

\section{RUMEN}

The main compartment of the special stomach of the cows, which is divided into other three.

\section{MICROBES}

Tiny forms of life, including bacteria, fungi, and protozoa.

\section{MICROBIOME}

Entire habitat, including the microbes (bacteria, archaea, fungi, protozoa), their genomes (i.e., genes), and the surrounding environmental conditions.

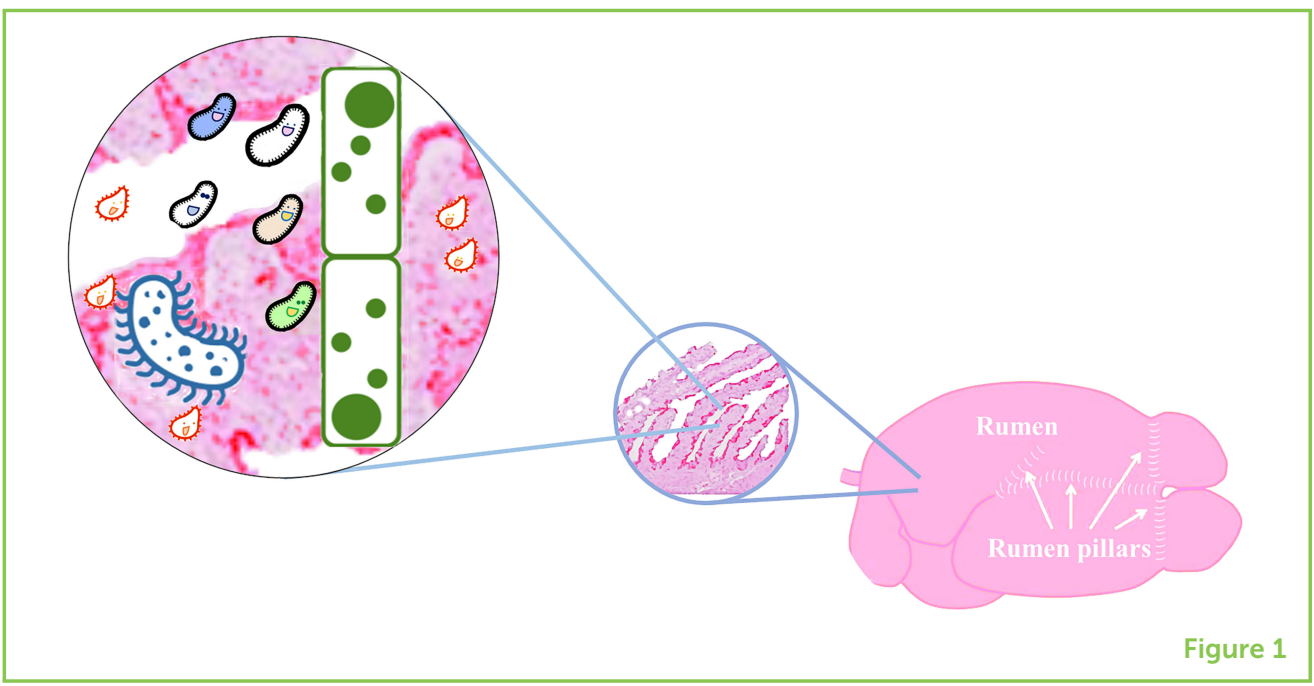

\section{DID YOU KNOW THAT COWS ARE RUMINANTS?}

Humans get many useful products from beef cattle. Not only do they provide us with a source of meat, but also leather, soap, gelatin and medicines come from cattle. Cows also eat foods that other animals cannot use up and live in land that is not suitable for building houses or growing plants for people to eat.

Cows are ruminants, which means they have a rumen. The rumen is the first part of a cow's four-part stomach. The rumen helps cows to break down tough materials like those found in plants, and the smaller, broken-down pieces are easier for the cows to use for food. Imagine having hands and tiny fingers inside your stomach. The hands, called pillars, squeeze the food up and down and all around in the rumen until it is squished into little pieces, while the fingers, called papillae, help to take nutrients from the food (Figure 1, right). Now imagine yourself repeating this process for $8 \mathrm{~h}$ a day! That is a lot of work! Cows are not the only ruminants-goats, sheep, and even giraffes and moose are ruminants too [1]! Wild ruminants, such as elk and caribous living in grasslands help to prevent a dangerous rise in greenhouse gasses in earth's atmosphere. Animals trim the grass constantly, helping the grass to grow taller and healthier. Their roots become longer, and the grasses can take up more of the greenhouse gas carbon dioxide from the atmosphere. Thus, wild, and grazing domestic ruminants protect the diversity of our native plants and animals, which are foods for humans.

\section{DID YOU KNOW THAT MICROBES CAN HELP COWS USE FOOD?}

The rumen is a special organ because it is home to millions of tiny, microscopic organisms called microbes. All the microorganisms together are called the cows' microbiome. Cows can eat plants as their 
Figure 2

Cows are about 1,000 times larger than their microbes. For comparison, if Mount Rushmore were a cow the small cow in the right corner of the mountain would be a bacterium. On the right side of the figure, you can see where archaea, bacteria, protozoa, fungi, cows, and humans are on the tree of life. The bottom of the tree includes less complex organisms and the top branches include those more complex.

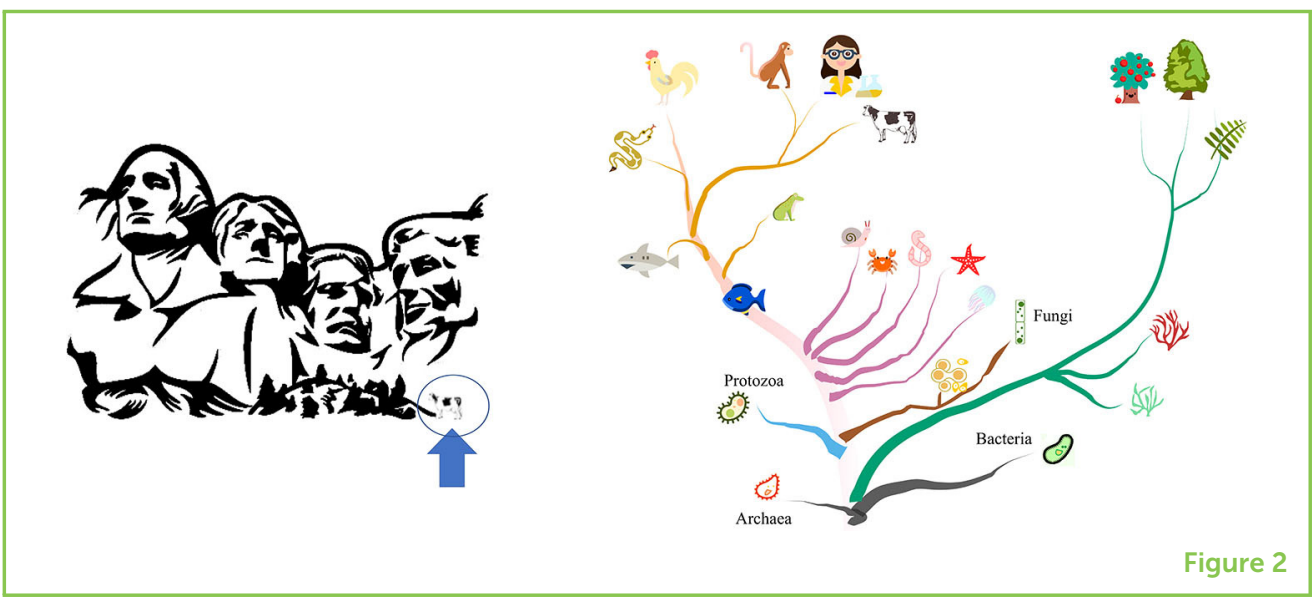

main food source because the rumen houses many different microbes that break the plants down into usable energy for the cows. Scientists have recently become aware that the microbiome is necessary for cattle to grow and be healthy [2], and scientists have been trying to help this microbe team to be more efficient [3]. More efficient microbes could mean healthy, bigger cows that eat less food. Although the scientists have worked hard to achieve this aim while increasing the environmental benefits, the results have not been as good. Scientists now know that there is much more information we need to piece together before we can support the cows' microbiome in its mission: getting as much energy as possible from less food, so cows can grow better and be happy.

\section{DID YOU KNOW THAT THERE ARE DIFFERENT KINDS OF MICROBES THAT DO DIFFERENT JOBS?}

Cows are around 1,000 times larger than the microbes living in their rumens (Figure 2, left). The cow microbiome is made up of squads of different kinds of microbes: bacteria, protozoa, fungi, and archaea. The types of microbes all have different abilities and there are many things that affect their behavior. Although cows and their microbes belong to different kingdoms of life (Figure 2, right), they collaborate, and both the cows and the microbes obtain positive results from this teamwork.

Bacteria and archaea are a lot smaller than fungi and protozoa (Figure 1, left). Bacteria can eat many different things and they produce several kinds of nutrients for the cow. Archaea are fewer and smaller, and they do not do as many different things as bacteria do. Fungi are good at breaking into tough plant walls. Protozoa can hold on to foods and store them longer than other microbes, so they can release energy when needed, to provide fast resources for the cow. To give you an idea of how many microbes of each type are present, if our microbiome team had 20 members, 10 would be in the bacteria 
squad, eight on the protozoa crew, and fungi and archaea would be represented by one participant each.

Beef cows can eat many kinds and parts of plants. For most of their lives, cows graze, meaning they eat grass. But as cows get older, they can eat grains. Grains, like cereal, come from the seeds of plants. Grains are not as hard to break down as grass, so the microbes can digest them faster than they digest grass. We know that diet is a big force driving the composition of the microbiome team [4]. If their preferred food is not present in the cow's diet, microbes will not grow and the members on the team will change. For instance, some bacteria can only live and grow when cattle eat mostly grains, but others are more adaptable and can survive [4]. Archaea are often found when cows are eating more plants. The protozoa squad does not change as much because of the diet, while fungi really do not like grains and will sometimes die off when cattle eat more grain.

Although microbes do a lot of important things for cows, they can also do things that are not as helpful. Some microbes produce methane, which is a gas that contributes to global warming and is also a waste product for cattle, preventing them from growing to their full potential. Some microbes might not make energy from certain foods as well as other microbes can. Scientists want to understand the helpful effects of the cows' microbiome while also making sure their microbes release less methane.

\section{DID YOU KNOW WE CAN HELP MICROBES HELP COWS?}

There are things that scientists and farmers can do to help the microbiome team do their best to grow happy, healthy cows. Like we mentioned before, cattle eat mainly grass when they are young, but they are usually fed more grain as they grow older. Grains are used not only to feed cattle, but also to produce food or fuels for humans. Grain leftover from other uses is a great food for cattle because protein and other nutrients contained in the grain can be broken down by the microbiome team. The broken-down grain can then be used by animals and help them to grow and be healthy. When this diet change from grass to grain happens, the microbiome helps cows to successfully pass from digesting plants and their mother's milk to eating grains. Of course, the microbiome must change to keep young cows healthy. Remember what happened when your mom or dad tried to feed you a new food for the first time? Maybe you felt that the texture was weird, maybe you even cried. Cows do not cry, but they get stressed when their food is changed. For this reason, letting cows try new foods early in life helps their microbiomes get used to breaking down different kinds of food. When the microbiome is adjusted to the new food, the cow can grow faster and be healthier. 
Scientists have created special foods or medicines that can be fed to cows to limit the growth of microbes that produce things that may be a waste for the cow, like methane. However, the positive effects of the special foods or medicines do not usually last very long. Scientists are trying to find longer-lasting, inexpensive ways to help microbes help cows use food better [5]. For example, do you like the smell of rosemary or thyme? The aromas of these spices are contained in the essential oils that come from these plants, which can eliminate particular microbes producing waste in the gut of the cows. Scientists are trying to learn if providing these oils to cows can help them to use their food better, because they may help to stop the activities of the bad microbes.

\section{ARE THERE ANY OTHER WAYS THAT SCIENTISTS ARE WORKING TO HELP ANIMALS AND THE ENVIRONMENT?}

As we have shown, a cow's microbiome is very important for helping the cow to grow, because the microbes participate in the breakdown of the foods that the cow eats, providing the cow with nutrients. Diet and other factors in the cow's environment can change how well the microbiome does its job, but we still need to find out exactly how this happens so that we can make beef production the best it can be. Researchers are trying to determine whether some microbes make different nutrients that might help cows to eat less but gain more weight. This type of knowledge will help to improve livestock farming. Knowledge about a cow's microbiome can also help us care for the environment, because we can maintain or help cow's growth, while decreasing the wasteful products released in the atmosphere and in the environment.

\section{REFERENCES}

1. Myer, P. R., Clemmons, B. A., Schneider, L. G., and Ault, T. B. 2019. Microbiomes in ruminant protein production and food security. CAB Rev. 14:1-11. doi: 10.10 79/PAVSNNR201914008

2. Hernandez-Sanabria, E., Goonewardene, L. A., Li, M., Mujibi, D. F., Stothard, P., Moore, S. S., et al. 2010. Correlation of particular bacterial PCR-denaturing gradient gel electrophoresis patterns with bovine ruminal fermentation parameters and feed efficiency traits. Appl. Environ. Microbiol. 76:6338-50. doi: 10.1128/AEM.01052-10

3. Clemmons, B. A., Martino, C., Schneider, L. G., Lefler, J., Embree, M. M., and Myer, P. R. 2019. Temporal stability of the ruminal bacterial communities in beef steers. Sci. Rep. 9:9522. doi: 10.1038/s41598-019-45995-2

4. Hernandez-Sanabria, E., Goonewardene, L. A., Wang, Z., Durunna, O. N., and Moore, S. S. 2012. Impact of feed efficiency and diet on adaptive variations in the bacterial community in the rumen fluid of cattle. Appl. Environ. Microbiol. 78:1203-14. doi: 10.1128/AEM.05114-11 
5. Clemmons, B. A., Voy, B. H., and Myer, P. R. 2019. Altering the gut microbiome of cattle: considerations of host-microbiome interactions for persistent microbiome manipulation. Microb. Ecol. 77:523-36. doi: 10.1007/s00248-018$1234-9$

SUBMITTED: 06 January 2020; ACCEPTED: 03 August 2020;

PUBLISHED ONLINE: 04 September 2020.

EDITED BY: Liesel G. Schneider, The University of Tennessee, Knoxville, United States

CITATION: Clemmons BA and Hernandez-Sanabria E (2020) Getting Big Cows by Feeding Their Tiny Microbes. Front. Young Minds 8:117. doi: 10.3389/frym.2020. 00117

CONFLICT OF INTEREST: The authors declare that the research was conducted in the absence of any commercial or financial relationships that could be construed as a potential conflict of interest.

COPYRIGHT @ 2020 Clemmons and Hernandez-Sanabria. This is an open-access article distributed under the terms of the Creative Commons Attribution License (CC BY). The use, distribution or reproduction in other forums is permitted, provided the original author(s) and the copyright owner(s) are credited and that the original publication in this journal is cited, in accordance with accepted academic practice. No use, distribution or reproduction is permitted which does not comply with these terms.

\section{YOUNG REVIEWERS}

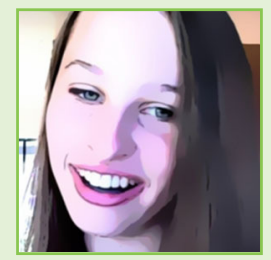

\section{MADDIE, AGE: 15}

My name is Maddie. I am 15 years old, and live near San Francisco.

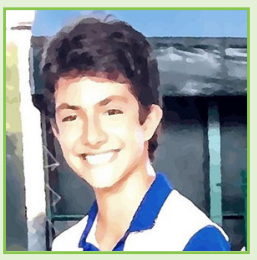

\section{MATÍAS, AGE: 14}

I am a 14 years old who loves science, programming, Vikings, mythology, Jiu-Jitsu, rock and roll, singing, and playing drums.

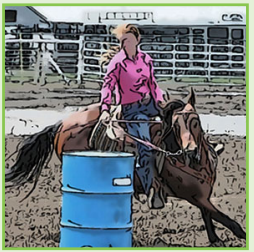

\section{SADIE, AGE: 15}

Sadie is active in volleyball, track, and band. She enjoys science and mathematics and is looking forward to Biology and Anatomy \& Physiology coursework. In her free time, she is training and competing in rodeo events including pole bending and team roping with her horses; Autumn, Calypso, and Coco. 

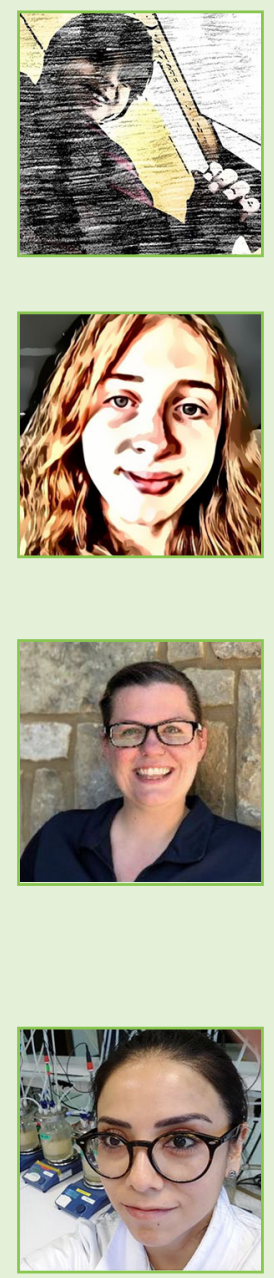

SEBASTIAN, AGE: 10

I like sports, reading, math, and animals.

\section{TACY, AGE: 13}

Hi I am Tacy. I am 13, and live near San Francisco. I like drawing, videogames, and playing guitar.

\section{AUTHORS}

\section{BROOKE A. CLEMMONS}

I am a Ph.D. student in Animal Science in Knoxville, TN. I grew up in cities, but always loved farm animals. I currently work with cows, and study how different things in their environments affect how cows use food. I specifically focus on how things like pregnancy and genetics affect the microbes that live in the gut of cows, and how we can use those microbes to make animals grow better and be healthier. *Brooke.Clemmons@atamuc.edu

\section{EMMA HERNANDEZ-SANABRIA}

I am a vet and I love cows and the bacteria living in our guts. My passion for studying both of these things took me to the University of Aberdeen (in Scotland) and The University of Alberta (in Canada) for post-graduate studies. I decided to continue seeing the world and I moved to Belgium, where I now work as a Post-doctoral Fellow at the Flemish Institute of Biotechnology (VIB) in Leuven. I use simulations of our gut environment to see how our microbiome changes in health and disease. *emma.hernandezsanabria@kuleuven.vib.be 